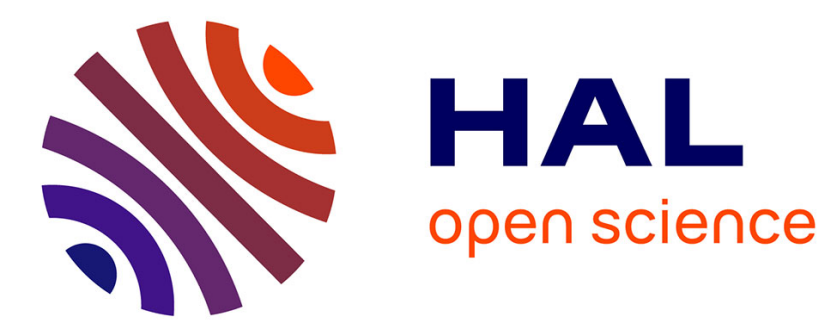

\title{
The impact of rent control: Investigations on historical data in the city of Lyon
}

Loïc Bonneval, Florence Goffette-Nagot, Zhejin Zhao

\section{To cite this version:}

Loïc Bonneval, Florence Goffette-Nagot, Zhejin Zhao. The impact of rent control: Investigations on historical data in the city of Lyon. Growth and Change, 2021, 10.1111/grow.12584 * halshs-03465125

\section{HAL Id: halshs-03465125 \\ https://shs.hal.science/halshs-03465125}

Submitted on 5 Jan 2022

HAL is a multi-disciplinary open access archive for the deposit and dissemination of scientific research documents, whether they are published or not. The documents may come from teaching and research institutions in France or abroad, or from public or private research centers.
L'archive ouverte pluridisciplinaire HAL, est destinée au dépôt et à la diffusion de documents scientifiques de niveau recherche, publiés ou non, émanant des établissements d'enseignement et de recherche français ou étrangers, des laboratoires publics ou privés. 


\title{
GATE $_{\text {vous surertement }}$
}

UMR 5824

93, chemin des Mouilles 69130 Ecully - France

Maison de l'Université, Bâtiment $B$ 10. rue Trefilerie 42023 Saint-Etienne cedex 02 - France http://www.gate.cnrs.fr gate@gate.cnrs.fr

WP 2119 - September 2021

\section{The impact of rent control: investigations on historical data in the city of Lyon}

\author{
Loïc Bonneval, Florence Goffette-Nagot, Zhejin Zhao
}

\begin{abstract}
:
This paper reexamines the debated issue of the effects of rent control policy on the rental market. We investigate the impact on rents of three different forms of rent regulation in Lyon over a 78-years period. We use an original historical dataset which allows us to track regulation changes, rent paid and tenant moves for a long-run panel of flats. Using a difference-in-differences method, we estimate the impact of regulation on rents depending on the type of rent control over different economic periods. Our results show that the impact of rent control deepened over time. Starting with a $11 \%$ reduction in rents between 1914 and 1929 , it reached a decrease by $47 \%$ in the regulated rental market in the 1949-1968 period. We do not find any increase in rents in the unregulated segment of the rental market, which could be a result of a reduction in housing investment in the long run.
\end{abstract}

Keywords:

Rent control; Housing policy; Difference-in-differences.

JEL codes:

R38; N93; N94

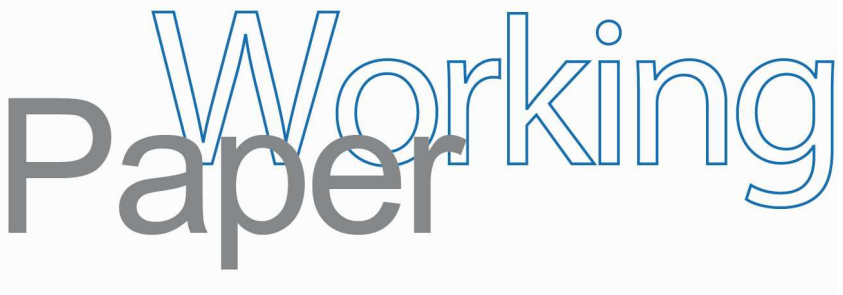




\title{
The impact of rent control:
}

\section{investigations on historical data in the city of Lyon}

\author{
Loïc Bonneval ${ }^{\mathrm{a}}$ \\ Florence Goffette-Nagot ${ }^{\mathrm{b}}$ \\ Zhejin Zhao ${ }^{c}$
}

September 2021

\begin{abstract}
This paper reexamines the debated issue of the effects of rent control policy on the rental market. We investigate the impact on rents of three different forms of rent regulation in Lyon over a 78-years period. We use an original historical dataset which allows us to track regulation changes, rent paid and tenant moves for a long-run panel of flats. Using a differencein-differences method, we estimate the impact of regulation on rents depending on the type of rent control over different economic periods. Our results show that the impact of rent control deepened over time. Starting with a $11 \%$ reduction in rents between 1914 and 1929, it reached a decrease by $47 \%$ in the regulated rental market in the $1949-1968$ period. We do not find any increase in rents in the unregulated segment of the rental market, which could be a result of a reduction in housing investment in the long run.
\end{abstract}

Keywords: Rent control; Housing policy; Difference-in-differences JEL Classification: R38; N93; N94

${ }^{a}$ Univ Lyon, Université Lumière Lyon 2, Centre Max Weber UMR 5283, F-69007 Lyon, France.loic.bonneval@univ-lyon2.fr

${ }^{\mathrm{b}}$ Univ Lyon, CNRS, GATE UMR 5824, F-69130 Ecully, France. goffette-nagot@gate.cnrs.fr ${ }^{c}$ Faculty of Business and Economics, University of Hong Kong, Hong Kong, China. zhaozj@hku.hk 


\section{Introduction}

Several countries experienced various degree of rent control in the past, including Canada, Germany, the United Kingdom and the United States. As to the recent period, a rent control law was passed in France in February 2014 and implemented in Paris since August 1, 2015. ${ }^{1}$ This law states that the rent of a dwelling cannot be higher than a cap defined as $20 \%$ above the median rent observed for dwellings in the same neighborhood, with the same number of rooms and construction period. ${ }^{2}$ In the context of rising housing prices, this law aims to constrain rent increases when a landlord lets a property for the first time or relets it, as rent increases within the course of a tenancy are already regulated. Capping rents or their increase rate seems to directly benefit consumers and especially low-income households. Yet, the full economic consequences of such an intervention on the housing market need to be carefully assessed.

There are, broadly speaking, two types of rent control policies. In the first case, rents are controlled both over the course of a tenancy and when the tenant changes. This is conventionally referred to as a first-generation rent control and it is the stricter form of rent control. In the second case, rent control is released when the tenant changes, which means rents are regulated only within a tenancy. This kind of rent control is commonly called a second-generation rent control policy.

There is some consensus among economists about the potential negative consequences of rent control. On one hand, this regulation is able to cap increases in rents immediately, but it may also have unexpected consequences. In a nutshell, a rent control policy might result in an increase of rents, both in the regulated and in the unregulated segments of the rental market. Firstly, the diminution of rental returns may reduce housing investment and thus housing supply, inducing a rent increase in both the regulated and the unregulated rental markets (Early, 2000; Diamond, 2019). Secondly, a second-generation rent control could lead landlords to increase rents upon new leases to compensate for the interdiction of rent increases during the lease, resulting in higher rents even in the regulated rental market as argued by Nagy (1997). The long-run impact on rents of a rent control policy is therefore questionable. Empirical evidence on the impacts of rent control is based on only a few cases and the magnitude of estimated effects varies across locations and over time, thus empirical 
analyses in different contexts are still required to lead to a better understanding of the equilibrium impacts of a rent control policy.

This paper attempts to contribute to this literature by considering a rent control policy over a long period of time, within a changing economic context in France, where rent control was used over the majority of the 20th century. Using historical data in the city of Lyon over a 78-years period, our study quantifies the effects of two types of rent regulation using a difference-in-differences identification strategy. Our data is taken from a property manager's account books covering the 1890-1968 period. This unique data allows us to track regulation changes, rent paid and tenant moves at the flat level. It gives us an original point of view on a period over which rent control was largely implemented in France but almost never evaluated using policy impact methods due to a lack of data. Our study shows that the impact of rent control became larger over time. Starting with a $11 \%$ reduction in rents between 1914 and 1929, it reached a decrease by $47 \%$ in the regulated rental market during the period 1949-1968.

The remainder of this paper is organized as follows. The next section details the literature review. Section 3 depicts the rent control history in Lyon and section 4 presents the data. Section 5 introduces the empirical strategy. Section 6 reports the results and section 7 concludes.

\section{Literature review}

Regulatory intervention on housing markets is broad and deep. Housing markets are governed by planning processes, zoning, land use regulations, financial regulations and numerous other rules, in which rent control is the most important regulation historically (Turner and Malpezzi, 2003; Gyourko and Glaeser, 2008).

The impact of rent control on equilibrium rent levels is controversial, as several mechanisms might hinder the expected rent stabilization. The first mechanism relates to the supply reduction that might be induced by rent control. Early (2000)argues that the likely effect of rent control is to lower the returns on investments in the controlled sector and decrease housing supply, thus the long-run, rents may be higher even in the controlled 
segments of the rental housing market. He uses New York City data in 1996 to test this hypothesis. The results suggest that tenants lost 44 dollars per month for households in rent stabilized apartments and 4 dollars per month for households in more strictly rentcontrolled housing. Tenants in the controlled sector would have been better off had rent control never been implemented in New York City. Sims (2007) uses a difference-indifferences strategy to estimate the impact of rent decontrol in Massachusetts, and finds that rent control encourages owners to shift housing from rental status to owner occupancy. In a recent paper, Diamond et al. (2019) show that rent control in San Francisco increased the probability of renters staying at their address by $20 \%$, reduced the supply of rental housing by $15 \%$, and led to a rent increase in the long run. They conclude that the rent control policy caused a substantial welfare loss.

Another mechanism is involved in the case of second-generation rent control. Nagy (1997) argues that landlords can set a higher price than the rents in an uncontrolled market at the beginning of a new lease in order to compensate for the fact that the rents will have to remain unchanged until the tenant changes. As the time goes, the rents paid by tenants in the controlled sector increase. As a consequence, the regulation may change nothing except alter the timing of payment. Nagy uses data from New York City during the period 19781987 to test this hypothesis and finds that new tenants paid higher rents in the controlled sector compared to those who occupied similar apartments in the uncontrolled sector. Still, tenants in the controlled sector paid less provided they stayed longer in their flat.

More sophisticated hypotheses can be made, however, under which a second-generation rent control policy produces the expected rent reduction. Raess and von Ungern-Sternberg (2002) propose a theoretical model of the rental market with search costs, switching costs and price discrimination caused by product heterogeneity, and show that with these features, a second-generation rent control leads indeed to lower equilibrium rents. Likewise, Basu and Emerson (2003) consider the effect of a second-generation rent control on rents and argue that its impact is similar to that of a first-generation rent control policy. Because of inflation and information asymmetry, landlords prefer short-staying to longstaying tenants, but they cannot distinguish which type a tenant is. Long-staying tenants have the incentive to conceal this information to prospective landlords. Considering this point, monopolistic landlords hold prices down to attract a "better quality" tenant (i.e. a 
short-staying tenant). Therefore, a second-generation rent control can reduce rental levels in a way that mimics first-generation rent control policies.

Not only is the impact of rent control in the controlled sector questionable, but rent regulation is also suspected to increase rents in the uncontrolled sector due to spillovers or general equilibrium effects. Indeed, if rent control reduces the supply of housing, the induced shortage in the whole housing market is likely to increase the rent in the uncontrolled segment of the housing market. Fallis and Smith (1984), using data for Los Angeles during the 1969-1978 period, find that rent control effectively raised rents in the uncontrolled segments of the markets. Caudill (1993) estimates the effect of New York City's rent controls in 1968 and finds that rents in the free sector would be lower by $22 \%$ to $25 \%$ if rent control did not exist. Hubert (1993) argues that rents in the uncontrolled sector can rise or fall after a rent control policy is implemented in a part of the housing market. If tenants can satisfy their needs in the controlled sector, they will reduce their demand in the free market, which results in a fall of rents in the free market. However, if tenants are unable or unwilling to obtain housing in the controlled sector, they have to go to the unregulated market, which may result in a rise of rents in this market. Based on a spatial equilibrium model, Heffley (1998) shows that tenants in both the controlled and uncontrolled zones can benefit from rent control, at the expense of landlords and the public sector. This result depends on the model specification and parameter values, but nonetheless highlights that the external effect of rent control depends on tenants economic and location decisions. Early and Phelps (1999) also claim that the effect of rent control on the uncontrolled sector is ambiguous, but using 1984-1986 data from the American Housing Survey, they find that the price in the uncontrolled sector increased since the introduction of rent control. Their interpretation is that rent control reduced the supply of rental housing. However, these effects decline through time and may disappear after several years. Some other authors concluded that rent control leads to higher rents in the uncontrolled sector (Navarro, 1985; Ho, 1992). For example, Early (2000) shows that the fraction of rental units under rent control is positive correlated with the pricing of rental housing in the uncontrolled sector. Autor et al. (2014) find that the unanticipated elimination of rent control in Cambridge, Massachusetts in 1995 raised housing values of both decontrolled and never-controlled residential properties, due to spillover effects.

Many other consequences of rent control policies have been studied, regarding housing supply, housing maintenance, residential mobility or benefits to renters. ${ }^{3}$ 


\section{History of the French rent control policy in the 20th century}

Before 1914, there was no public regulation of rents in France. In 1914, due to the burden of World War I, renters were allowed not to pay their rent for periods up to 90 days if the rent was below a ceiling set to 600 Francs (Fr) in Lyon. The associated temporary eviction moratorium lasted throughout the World War I period.

Between World Wars I and II, a special regime was put in place, in a context where the shortage of housing and the economic situation required the protection of renters. This was an explicit rent control policy, with a regulation applying to rent increase rates, with the 1914 level as the reference level. In fact, a complex system of accumulating successive rules was implemented. In a nutshell, it mainly consisted in two rules: first, the regulation of nominal rent increase rates within tenancies; second a ceiling, determined by the law and adjusted over time, above which rents were released from the regulation. These two rules are represented on Figure 1, with allowed rent levels compared to the 1914 rent level and ceiling adopted in different years. For example, in Lyon in 1926, nominal rents could not exceed twice their 1914 level, meaning the allowed rent increase rate was actually less than the inflation rate. The nominal rent ceilings decreased and changed seven times in total over the period. For instance, rents above $9000 \mathrm{Fr}$ were not controlled anymore in 1928. The last change happened in 1942: all rents above $250 \mathrm{Fr}$ were not controlled anymore.

A significant change occurred in 1930, when the control started applying even when the tenant changed, which was not the case before. Apart from this change, the regulation was similar as during the previous period. We can thus consider the rent control policy implemented in Lyon during the 1914-1929 period as a second-generation rent control, followed by a first-generation rent control from 1930 to 1948.

A new law was passed in 1948, which aimed to end the special rent regime and increase the return of housing properties in order to favor housing construction and maintenance. A reference rent was computed based on the flat characteristics such as location, maintenance and quality. Biannual increases were then applied for the rent to reach this reference rent by 1955. Continued leases ensured a capped rent increase, but flats were released from this regulation upon tenant change. The 1949-1968 period can therefore be considered as a rent control of second-generation type. It is worth noting that the incentive for tenants to stay in 
the apartment or to subcontract was high, in a context of rising rents following the strong contraction of rents imposed by the rent regulation of the previous period.

A summary of these different phases of the rent control policy is presented in Table 1 . Importantly, the rent regulation was meant to protect low-income renters and therefore did not apply to flats for commercial-use like shops or craftsmen workshops. This policy was applied at the national level, and Lyon, as one French major city, is a relevant study case.

\section{Data}

\subsection{Data source}

This study uses data collected from a real estate property manager's accounting books covering the 1890-1968 period. These books were used to register, for each building managed by the company, all the rents paid by tenants, and all the expenditures at the building level. These information were collected and processed by Bonneval and Robert (2009L)(see Bonneval and Robert, $\underline{2009}$ for a detailed description of the original data). The company managed upper middle class real estate in the 19th and 20th centuries, mainly in the central area of Lyon, which explains the average observed rent being generally higher than that in the whole of Lyon. ${ }^{4}$ Nonetheless, the observed sample is sufficiently heterogenous to offer an acceptable representation of buildings in the central area of Lyon as shown in Figure 2. Some sample attrition occurs because low quality buildings were more likely to be demolished during the urbanization process in the period under study. This data allows us to compare controlled and uncontrolled rents over a long historical period; there is no other data source in France which allows for this to our knowledge.

This data provides flat-level information including whether the flat is used for housing or commercial use, the tenant name, the rent paid, the number of rooms, floor area, an indicator of quality category and rent control status. Comparing tenant name in subsequent periods allows detection of tenant changes. The construction period and construction type, number of floors, total built surface area, and geographical coordinates are registered at the building level. 
The original sample is an unbalanced panel of about 500 flats. It has 32,745 records, each of them corresponding to a rent payment by a given tenant in a given period (year or semester). Some observations are dropped from the original sample due to missing information on flat use (66 observations) and floor area or number of rooms (1,438 observations). Information about tenant change is imputed for 43 observations for which it is missing. We assume there were no tenant changes in these instances. Rents registered at the semester level are summed to get yearly rents. Regarding control status, if one flat is controlled at least one semester in a year, we assume it was controlled for the whole year. All monetary amounts are transformed in 1999 Francs using inflation coefficients taken from Friggit (2002). The final sample consists of 19,638 records, for 393 flats, of which 292 are housing units and 101 flats in commercial use. 235 flats are observed almost continuously for the whole study period. 86 flats enter the sample before 1914 but disappear before 1949. The remaining 72 enter the sample later than 1914.

\subsection{Descriptive statistics}

Table 2 presents the yearly average of the number of flats in the sample, by subperiods and control status. The number of flats managed by the property manager varied roughly speaking between 220 and 290 depending on period. About a quarter of them were flats in commercial use, which were actually shops or workshops located at the ground floor of the managed buildings.

Almost all residential flats had regulated rents between 1914 and 1929. Only a few were uncontrolled because their initial rent exceeded the ceiling for regulation. During the subsequent period (1930-1948), about one-third of residential flats were regulated, although this figure varied over time, from $94 \%$ at the start of the period to $0 \%$ by the end, as a consequence of flats being progressively released from control (see Figure 3 ). The average share of controlled rents over the 1949-1968 period was higher with 65\% of controlled residential flats, and still $40 \%$ of controlled flats in 1968. As previously stated, rent control was released upon a tenant move, which gave high incentives for tenants to stay in their flat or to subcontract (which was a largely adopted practice), therefore exit from the regulated status was limited.

Figure 4 shows the observation period and rent control changes for each flat in the sample. One important feature of our dataset is the observation of flats for long periods of time, 
which allows us to monitor rent changes while controlling for flat quality. As explained in the next section, our estimation strategy exploits variations in control status for each flat to estimate the impact of the different types of rent control policies implemented during the period.

Figure 5 presents the rent changes in constant Francs disaggregated by flat use and control status, and Figure 6 presents the same changes in current Francs in logarithm. Overall, this period was characterized by large rent variations, both in constant and nominal Francs. Rents of both commercial and residential flats reached their lowest levels in constant Francs (Figure 5) just after World War I and World War II. It is worth noting that flats in commercial use experienced much larger rent variation than residential flats. Before 1914, rents of housing units were steadily increasing. The introduction of rent regulation was followed by a sharp decrease, which continued for flats under regulation until 1948. Flats which were released from control had, by definition, higher rents. Still, they experienced rent decreases over time, both in constant Francs and in nominal values. Although one observes on Figure $\underline{5}$ that these rent decreases occurred while flats in commercial use experienced rent increases (1926-1935 period), the low number of uncontrolled residential flats during this period (there were less than 30 controlled residential flats before 1935) makes this comparison less meaningful.

Table 3 presents descriptive statistics by time period and rent control status. On average, for all periods, flats subject to rent control were smaller than residential uncontrolled flats. There is however variability within each group, as shown by large standard errors, so these differences are not significant. Flats under regulation were also more frequently in lower quality buildings, with a higher share in ancient buildings as opposed to buildings constructed during the Haussmann period. However, all buildings in the sample include flats which have been subject to rent control. The relatively lower quality of controlled flats is more apparent at the floor level, with segregation occurring vertically at this time due to the absence of elevators. The distribution of flats by floor level indeed shows that controlled housing units were more frequently on the highest floor levels. There is no significant difference in location between controlled and uncontrolled residential flats, apart from the location of shops being predominantly in the two central districts. 
As will be explained in the next section, our identification allows to control for differences in the characteristics of controlled and uncontrolled flats, by exploiting control status changes for each flat.

\section{Empirical strategy}

Our aim is to estimate the impact of the rent control policy on the rental housing market over time. More precisely, our goal is twofold. Firstly, we want to evaluate the stringency of the different forms of rent control in Lyon over the whole period when rent control was ongoing. Specifically, the complex and evolving rules regarding the rent ceilings and caps on rent increase rates do not allow for precise identification of which rent reductions were induced by policy. By comparing the evolution of rents for flats on which control was applied to that of others, we will be able to give an account of the real impact of the rent control policy. Secondly, we want to attempt to evaluate a possible impact of rent control on uncontrolled housing units, that is, the externalities of the policy on the uncontrolled segment of the housing market.

To do so, we exploit rent control status variations across time periods and flats and use a difference-in-differences ( $\mathrm{DiD}$ hereafter) identification strategy based on a classic double fixed effects estimation. Generally speaking, the $\mathrm{DiD}$ strategy consists of estimating the impact of a treatment (here, the rent control policy) on a group of individuals, by comparing their evolution to that of a control group. The control group has to be defined such that it can represent the evolution of housing prices that would have occurred, would the rent control not have been introduced.

Considering the three different phases in the rent control policy implemented in Lyon during the observation period, the difference-in-differences method can be implemented by estimating the following equation:

$$
\ln y_{i t}=\alpha_{i}+\lambda_{t}+\mu_{t} S_{i}+\beta_{1} c_{1 i t}+\beta_{2} c_{2 i t}+\beta_{3} C_{3 i t}+\varepsilon_{i t}
$$

where $\ln y_{i t}$ represents the logarithm of rent of flat $i$ in year $t, \alpha_{i}$ is a flat fixed effect, $S_{i}$ is a dummy taking value 1 if the flat is in residential use, and $\lambda_{t}$ are year dummies that control for the general evolution of real estate prices, and $\mu_{t}$ are year dummies that are interacted 
with flat use in order to allow housing units to have specific trends relatively to shops. $C_{1 i t}$ is a dummy taking value 1 if the rent of flat $i$ was controlled during the 1914-1929 period (when a second-generation rent control policy was implemented), $C_{2 i t}$ is a dummy taking value 1 if the rent of flat $i$ was controlled during the 1930-1948 period (when the rent control policy changed to a first-generation type), $C_{3 i t}$ is a dummy taking value 1 if the rent of flat $i$ was controlled during the 1949-1968 period (when again a second-generation rent control policy was implemented), and $\varepsilon_{i t}$ is a classical error term. In the baseline estimations, the standard errors are clustered at the flat level, and then at the building level as a robustness check.

The flat fixed effects capture time-constant flat-specific factors affecting the rents. They allow control for differences in unobserved quality depending on control status. With these flat fixed effects, the impact of the policy is identified through changes in the control status for each flat. The year dummies control for the general evolution of rents in the observed period. Interactions of flat use with year dummies allow for specific trends for housing units relatively to shops, consistently with the observation of differing evolutions. The main coefficients of interest are $\beta_{1}, \beta_{2}$ and $\beta_{3}$, which in such a difference-in-differences setting can be interpreted as the causal effect of the three types of rent control on rents. They are based on the comparison of the evolution of rents of flats subject to rent control to that of flats belonging to the control group.

The control group comprises two types of observations: (1) flats which were never controlled in the observation period; as will be clearer later, all of them are actually flats in commercial use, to which rent control did not apply; (2) flats which are not controlled in each year. ${ }^{5}$ The first type of control observations is what is commonly used in a differencein-differences strategy. The second type can be used here as we have a staggered adoption design, and more specifically a non-monotonic treatment, meaning that the policy does not apply at the same date for all flats, as explained previously (see also Figure 4). Uncontrolled housing units are the most natural control group for estimating the impact of the rent control rules. However, they are likely to be subject to externalities from the controlled segment due to substitution effects between the two segments. As a robustness check, we will consider alternative definitions of the control group, especially by restricting it to commercial flats. 
Our data is an unbalanced panel of rental units, as shown on Figure 4. However, the DiD method requires the observation of treated individuals before the treatment starts. Furthermore, to avoid uncontrolled composition effects, it is desirable for the control group to remain the same over the estimation period. Thus, we restrict the estimation sample to units which are observed before rent control began, and are still observed during the treatment period. ${ }^{6}$

The selection of a quasi-balanced panel of flats over the 1890-1968 period is restrictive, as it yields a sample of 235 observations, as compared to 437 in the initial sample. Hence, we estimate the model for shorter subperiods, which allows us to keep a larger sample and therefore get more precise estimates. More specifically, we first estimate the impact of the rent control policy in place between 1914 and 1929 based on a sample of rental units observed at least once before 1914, and at least once after 1914. We then extend the period and estimate the impact of the two rent control regimes implemented successively between 1914 and 1948, based on a quasi-balanced sample of flats observed before 1914 and still observed after 1929. Finally, we estimate the impact of the three rent control regimes between 1914 and 1968, based on a quasi-balanced sample of flats observed before 1914 and still observed after 1948. We also estimate the model on the whole sample, without any restriction, which means we also keep flats that were not selected in the previous samples. 72 of these flats appear in the database later than 1913, and 15 are observed only before 1914 and after 1929.

A crucial assumption for the DiD method to yield valid results is the parallel trend assumption, according to which the evolution of the outcome for the treated and control groups, absent the treatment, would be the same. We test for this assumption by comparing the evolution of rents before rent control, for the group of flats that are later controlled, and the group which remains untreated. To do so, we run the following regression over the estimation samples used for the main results:

$$
\ln y_{i t}=\alpha_{i}+\lambda_{t}+\beta_{0} c_{0 i t} \times \nu_{t}+\varepsilon_{i t}
$$

where $t<1914, C_{0 i t}$ is a dummy taking value 1 if the flat is controlled at least once during the rent control period, and $\nu_{t}$ is a year dummy. The parallel trend assumption requires that the coefficients $\beta_{0}$ are all non-significantly different from zero. This equation is estimated 
on subsamples defined following the same rules as for the main model: flats present during the first two, first three and first four subperiods, and whole sample.

We also perform robustness checks by changing the control group. We consider the baseline model (1) over the whole period (1890-1968) but apply two restrictions successively. First, we want to deal with the fact that flats which have been subject to rent control can leave it, especially following a tenant move. In our baseline estimation, these flats are included in the control group when they leave treatment. To check if the presence of these previously controlled flats in the control group impact our results, we run an estimation in which they are discarded from the sample once they are released from rent control. The control group then only includes flats before they start being controlled and shops. Second, we go a step further by keeping only shops in the control group. However, a remaining limit of this empirical design is that tenant moves, which determine the release from rent regulation for each flat, could be caused by rent evolution. We will keep this in mind when commenting on our results.

\section{Results}

In the following, we present regression results for Equation (1), in which separate coefficients for the rent control policy applied in different subperiods are estimated, so as to evaluate the impact of the different rent control regimes. As a reminder, between 1914 and 1929, the rent control was of second-generation type, then turned to first-generation between 1930 and 1948, and turned back to a second-generation type with regulated capped rent increases during leases in 1949.

Before presenting these results, we first show the results of the common trend assumption test. This test is based on the estimation of equation (2) and is conducted on four different samples corresponding to the samples used to estimate the main model. Estimated coefficients for year dummies specific to flats which enter rent control at some point during the 1914-1968 period are plotted in Figure 7.Given the logarithm form of the explained variable, these coefficients represent the rent variation in percentage for housing units subject to rent regulation as compared to never-controlled flats. For all subsamples considered, none of these coefficients are significantly different from 0 at the $5 \%$ level, 
except for year 1898. This means that, after controlling for time-constant flat heterogeneity, the rate of change in rents for residential flats (which will all be controlled at least for some time starting in 1914) is similar to that of commercial flats. This justifies using commercial flats only, or commercial flats together with residential flats as control observations.

Table 4 shows the main regression results. Column (1) focuses on the impact of rent control during the first phase of the policy, from 1914 to 1929, Column (2) on the first and second phases, between 1914 and 1948 and Column (3) on the whole period. In each case, the largest possible quasi-balanced panel is selected. In Column (4), all available observations are kept in the sample, which means that 72 flats not selected in the three previous samples are added in the estimation sample.

According to Column (1), the rent control rules implemented starting in 1914 implied a decrease in rents by $24 \%$. This impact is estimated over a sample of 306 flats. The same impact estimated on a subsample of flats observed over a longer period (274 flats observed before 1914 and beyond 1930, Column (2)) is very similar, and the difference between the two estimated coefficients is not statistically significant. The estimated impact on flats observed for longer are even stronger, around 36\%, but given the associated standard errors, equality with the coefficient in Column (2) cannot be ruled out. However, this increase in the coefficient means that flats which disappeared after 1929 were not those which were the most impacted by rent control. The result of the estimation based on the whole sample shown in Column (4) is in line with the previous one. This observation implies that there are little differences in the impact of rent control between flats which started to be managed by the property manager after 1914 and others. Note that although the sample size decreases significantly when considering larger time periods (Columns (2) and (3)), standard errors are overall not much affected. As a robustness check, we also estimated the model with standard errors clustered at the building level (standard errors in squared brackets in Table 4 and 5), which only slightly changes the coefficients significance.

For the rent control rule which started in 1930, results in Columns (2) to (4) show that the impact of rent control was smaller than in the previous period. The rent reduction is indeed between $9 \%$ and $17 \%$ depending on the estimation sample. This lower impact of the policy is at odds with the idea that the rent control policy became more stringent in this period, when rent increases were capped even upon tenant changes. However, it is worth recalling 
that the 1930's were a period of economic crisis. As shown on Figure 6, rents of uncontrolled flats stagnated in current Francs and even decreased in constant Francs (Figure 5). As rent change caps were applied on nominal rents, this can explain the moderate impact of the policy in constant currency. Here, as in the case of the first rent control policy, comparing Columns (3) and (4) with Column (2) shows that considering flats that stayed longer in the sample amplifies the estimated impact.

Finally, estimated coefficients for the impact of the rent control policy imposed by the 1948 law suggest that this policy did not significantly alter rent evolutions relatively to the control group. This result can be surprising given that the 1948 law is viewed in France as having had large impacts on the rental market. Two points can possibly explain our result. First, the 1948 law allowed regulated rent increases for controlled housing units. Its goal was indeed to dampen the depreciation impacts of the previous rent control policy while still keeping rent growth reasonable. Second, although landlords could and did increase the rent when starting a new lease, they were probably less induced to do so during a continuing lease. As shown on Figures 5 and 6, flats subject to regulation, which are defined as flats with a continuous lease starting in 1948 or earlier, indeed experienced rent augmentations. The annual increase rate in this group was $7.9 \%$. By comparison, rent increase rates within a lease for flats released from rent control, were much lower, with $0.8 \%$ on average. In actuality, rent increases occurred between leases, with rent increase rates equal to $8.1 \%$ on average. Observing associated standard deviations $(27.1 \%, 71.6 \%$, and $38.8 \%$ respectively) shows that there is, however, a large variability within each of these groups. It is important to keep in mind one limit of the analysis, which is that tenant moves, and hence treatment exit, are likely to be caused by rent changes and therefore be endogenous.

The observation that rent increases remained low for flats released from control could be viewed as an externality of rent control on the uncontrolled segment of the rental market. It is worth noting that the share of controlled residential flats decreased steadily over time as the consequence of tenant mobility, but remained above $40 \%$ for practically the whole period. This is explained by the decrease in residential mobility, which can be viewed as a result of this policy, with an average annual mobility rate of $6.6 \%$, against $11.4 \%$ before 1914, 10.5\% from 1914 to 1929, and 7.5\% between 1930 and 1948. (See Figure 8) This apparent decrease in mobility was also the consequence of subcontracting arrangements 
that were a common practice during this period. This practice made finding a flat under control a possible option on the rental market, giving incentives to landlords to limit rent increases, even once the flat was not subject to control anymore.

The externalities from the rent control policy on unregulated housing units can be further investigated by looking at different definitions of the control group. Table 5 shows estimated coefficients for the baseline control group, and for two variants, in which firstly, flats that have been released from rent control are dropped from the control group (Column (2)) and then, only flats in commercial use (hence never controlled) are included in the control group (Column (3)). Note that only few not yet treated housing units are used in the control group in Column (2), so that the two control groups are in fact quite similar.

As shown on Figure 3, the share of controlled housing units varies widely across years, and so does also the composition of the control group in the baseline estimation. This composition effect is avoided when the control group includes only commercial flats. (Column (3) in Table 5).

The estimated impact of rent control during the 1914-1929 period is lower when only commercial flats are taken as control group, although the large standard error of the previously estimated coefficient is such that the difference is not statistically significant. This higher impact is consistent with the rule according to which flats with rent higher than a threshold were released from control. There is thus a selection of high rent flats in the group under control, which is not the case when only shops are included in the control group.

Restricting the control group intensifies, on the contrary, the negative effect of the 19301948 rent control rules on rents. This higher impact is consistent with the observation that the share of flats released from rent control increases over time during this period, such that there is then a significant proportion of residential flats in the baseline control group (see Figure 3). As these housing units are likely to be subject to externalities from the regulated segment, their price is likely to decrease over time following the rent evolution of the controlled segment, hence reducing the estimated impact of rent control. This does not happen when shops only are included in the control group. 
The same observation can be made for the impact of rent control after 1948. Dropping flats from the control group once they have been released from control strongly amplifies the estimated effect of rent control, which becomes then statistically significant, consistent with the average evolution of rents presented on Figure 5. This can be interpreted as showing a strong externality effect of rent control on non-regulated flats during this period.

One can discuss the use of flats in commercial use in the control group. On one hand, these flats are located in the same buildings as residential flats in our sample, and are therefore subject to the same real estate market evolutions. On the other hand, they are not perfect substitutes to housing units and might be subject to specific evolution. Nonetheless, we think they are a good control group, especially as they are less subject to externalities from the rent control policy.

As a last comment on our results, it is worth attempting to interpret the difference between the three rent control policies that were implemented over this period. According to estimated coefficients in Column (3) of Table 5, the impact of rent control on rents deepened over time. Starting with a 11\% reduction in rents between 1914 and 1929, it reached a decrease by $47 \%$ in the regulated rental market in the $1949-1968$ period. These differences should be considered relative to the general evolution of the real estate market. In the first subperiod, rents were still appreciating in nominal terms, flat with rents reaching thresholds were released from control, and rent increases were allowed upon tenant moves, all three factors which might explain the moderate impact of rent regulation. In the following period, the introduction of a first-generation rent control implied stronger effects on rents, both in the regulated segment and the unregulated segment, as a result of externalities of the former on the latter. During the last period, the rent regulation policy constrained rents even more intensely, even if capped rent increases were allowed for controlled housing units. Only tenant moves allowed for the release of control, and subcontract arrangements reduced such occurrences. Additionally, the large share of flats with controlled rents created a heavy externality of rent control on uncontrolled housing units. 


\section{Conclusion}

Few studies of rent control policies in Europe have been carried out. This paper attempts to contribute to this literature by considering a rent control policy over a long period of time, within a changing economic context in France. Using historical data in the city of Lyon over a 78-years period, our study quantifies the effects of three rent regulation policies using a difference-in-differences identification strategy. Our unique data allows us to track regulation changes, tenant moves and rent paid at the flat level for an extended panel data, giving us an original point of view on a period with almost no existing datasets.

Because flats for commercial use were not subject to rent control, they are included in the control group in the difference-in-differences estimation, together with housing units which are not subject to rent control in a given year. We checked based on the pre-regulation period that flats in commercial use and residential flats have comparable rent change rate. We also use two variants of the control group, firstly excluding residential flats having been released from control, and secondly keeping only flats in commercial use.

Our results show that the rent control imposed during the 1914-1929 period had the strongest depreciation impact on rent levels if we compare controlled flats with uncontrolled residential flats. However, this impact dependent on the specific rule according to which flats whose nominal rent reached a threshold were released from control. Using commercial flats only as a control group strongly reduces the estimated impact. The impact of rent control on rents deepened in the subsequent two periods. Starting with a 11\% reduction in rents between 1914 and 1929, it reached a decrease by $47 \%$ in the regulated rental market in the 1949-1968 period. These differences should be placed in perspective relative to the general evolution of the real estate market. In the first subperiod, rents were still appreciating in nominal terms, rents reaching thresholds were released from control, and rent increases were allowed upon tenant moves. In the following period, the introduction of a first-generation rent control implied stronger effects on rents. During the last period, the rent regulation policy constrained rents even more intensely, even if capped rent increases were allowed for controlled housing units and the large share of flats with controlled rents created a heavy externality of rent control on uncontrolled housing units. 
This study thus highlights the varying impacts of rent control, depending on precise mechanisms of regulation and economic context. More important, it points to the absence of any unexpected increase in rents due to the rent control policy, neither in the regulated nor in the unregulated segments of the rental housing market, contrary to predictions of some theoretical models. 


\section{References}

Autor, D. H., Palmer, C. J., and Pathak, P. A. (2014). Housing market spillovers: Evidence from the end of rent control in Cambridge, Massachusetts. Journal of Political Economy, 122(3):661-717.

Basu, K. and Emerson, P. M. (2003). Efficiency pricing, tenancy rent control and monopolistic landlords. Economica, 70(278):223-232.

Bonneval, L. and Robert, F. (2009). L'immobilier de rapport : forme urbaine, rapports de locations et stratégies patrimoniales. Le cas de Lyon (1860-1990).

Caudill, S. B. (1993). Estimating the costs of partial-coverage rent controls: A stochastic frontier approach. The Review of Economics and Statistics, 727-731.

Diamond, R., McQuade, T., and Qian, F. (2019). The effects of rent control expansion on tenants, landlords, and inequality: Evidence from San Francisco. American Economic Review, 109(9):3365-94.

Early, D. and Phelps, J. (1999). Rent regulations' pricing effect in the uncontrolled sector: An empirical investigation. Journal of Housing Research, 10(2):267-285.

Early, D. W. (2000). Rent control, rental housing supply, and the distribution of tenant benefits. Journal of Urban Economics, 48(2):185-204.

Fallis, G. and Smith, L. B. (1984). Uncontrolled prices in a controlled market: the case of rent controls. The American Economic Review, 74(1):193-200.

Friggit, J. (2002). L'évolution sur longue période du prix des logements. note de synthèse du SES (Service des études et de la statistique), Ministére de l'Equipement. 
Gross, M. (2020). The Long-Term Impacts of Rent Control. Job-Market Paper, University of Michigan.

Gyourko, J. and Glaeser, E. (2008). Rethinking federal housing policy. American Enterprise Institute.

Heffley, D. (1998). Landlords, tenants and the public sector in a spatial equilibrium model of rent control. Regional Science and Urban Economics, 28(6):745-772.

Ho, L. S. (1992). Rent control: its rationale and effects. Urban Studies, 29(7):1183-1189.

Hubert, F. (1993). The impact of rent control on rents in the free sector. Urban Studies, $30(1): 51-61$.

Malard, L. and Poulhès, M. (2020). Encadrement des loyers à paris: les logements à petites pièces plus contraints que les autres. report.

Nagy, J. (1997). Do vacancy decontrol provisions undo rent control? Journal of Urban Economics, 42(1):64- 78.

Navarro, P. (1985). Rent control in Cambridge, mass. The Public Interest, (78):83.

Raess, P. and von Ungern-Sternberg, T. (2002). A model of regulation in the rental housing market. Regional Science and Urban Economics, 32(4):475-500.

Sims, D. P. (2007). Out of control: What can we learn from the end of Massachusetts rent control? Journal of Urban Economics, 61(1):129-151.

Turner, B. and Malpezzi, S. (2003). A review of empirical evidence on the costs and benefits of rent control. Swedish Economic Policy Review, (10). 
Figure 1: Ceilings on relative rent increases

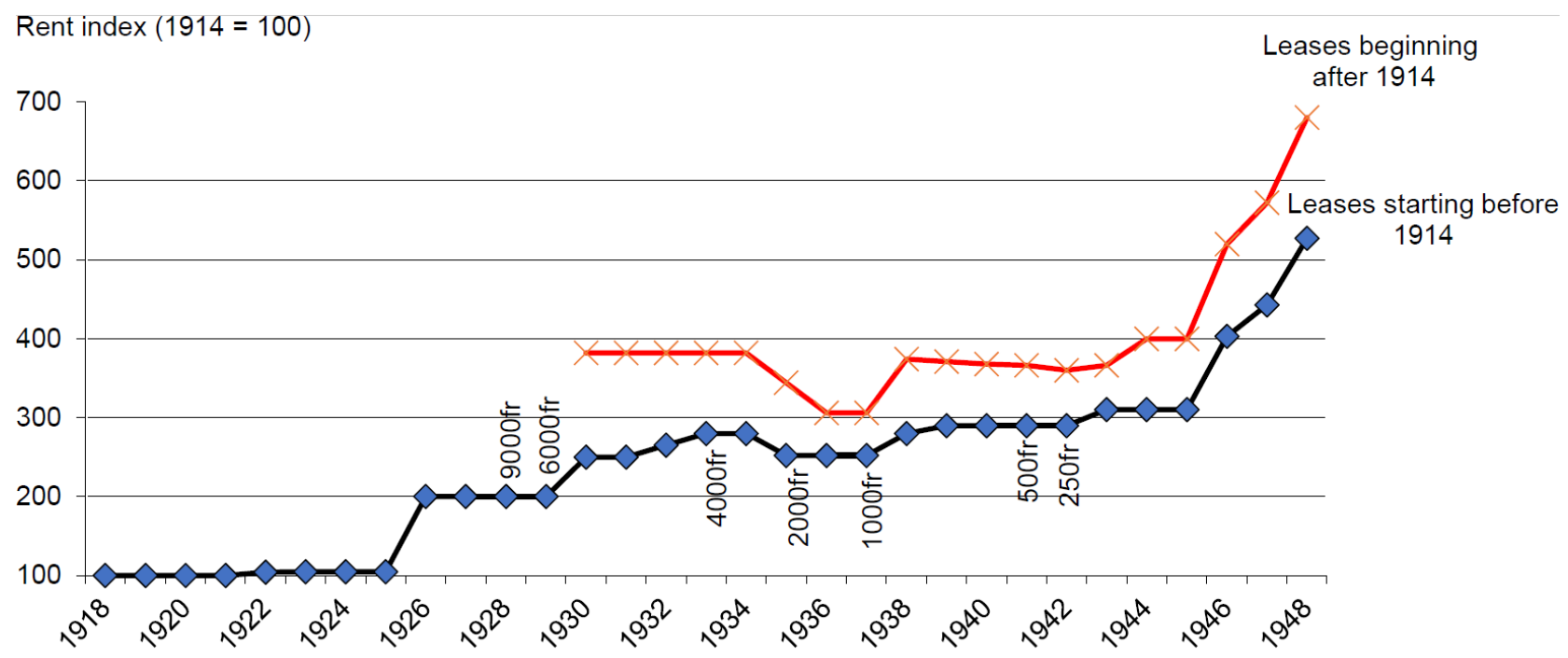

Data Source: Bonneval and Robert(2009).

Note: Rent index 100 corresponds to the rent in 1914, which is known for all flats even for leases starting after 1914. Between 1928 and 1947, flats were released from rent control when a change of tenant occurred or when the rent reached a ceiling (as shown with diamonds symbols on the graph). For instance, starting on 1928, flats with a rent above $9000 \mathrm{Fr}$ are not controlled anymore. Starting in 1930, all rents are capped excepting those exceeding a ceiling. From 1949 to 1968, rents subject to control are allowed to increase following legal rates until the tenant moves. 
Figure 2: Geographical locations of 25 buildings covered in the sample

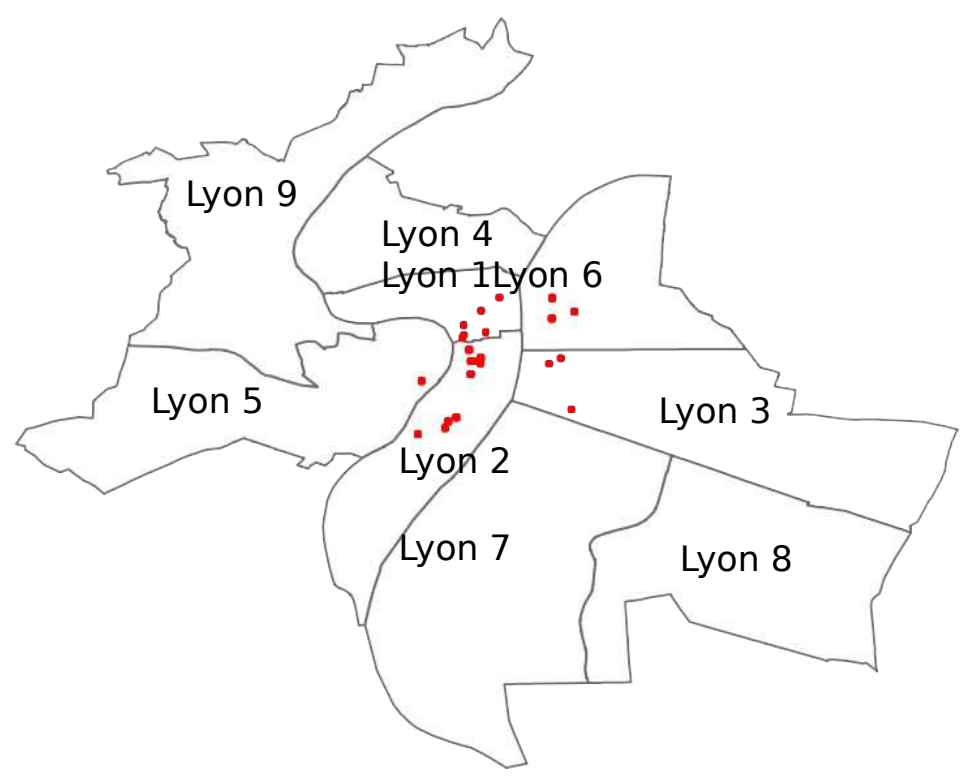

Figure 3: Yearly share of residential flats subject to rent control

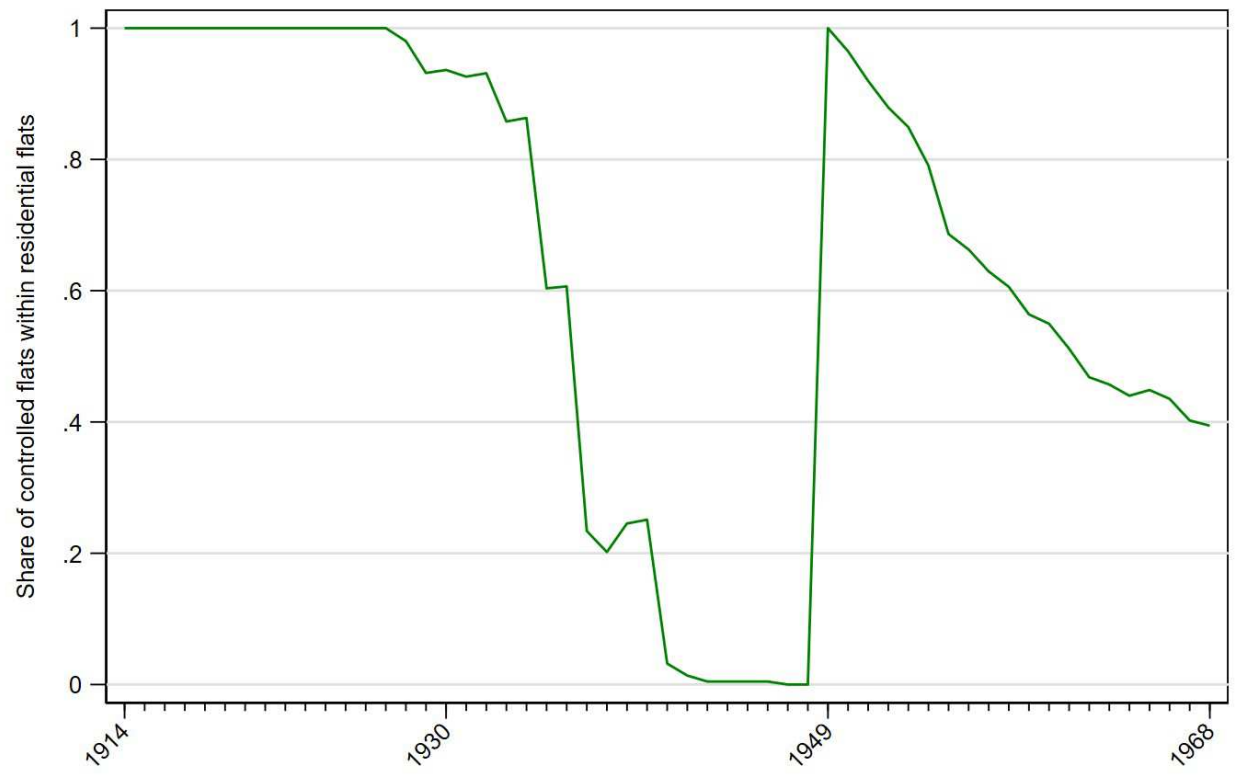


Figure 4: Rent control status for each residential flat in the sample

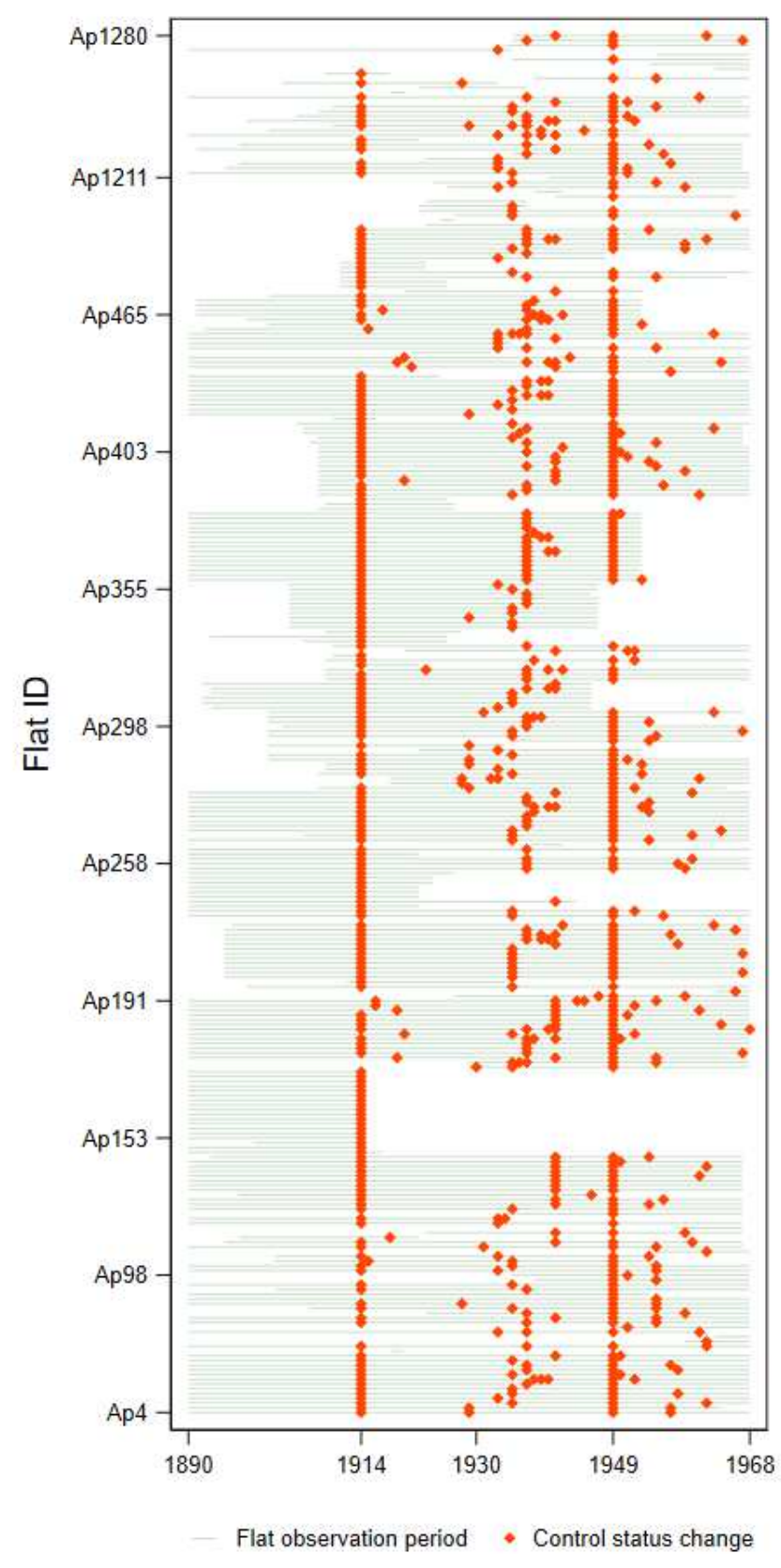

Notes: The red dot means that the control status changed from uncontrolled to controlled or from controlled to uncontrolled. 
Figure 5: Average rents of controlled residential flats, uncontrolled residential flats and commercial flats

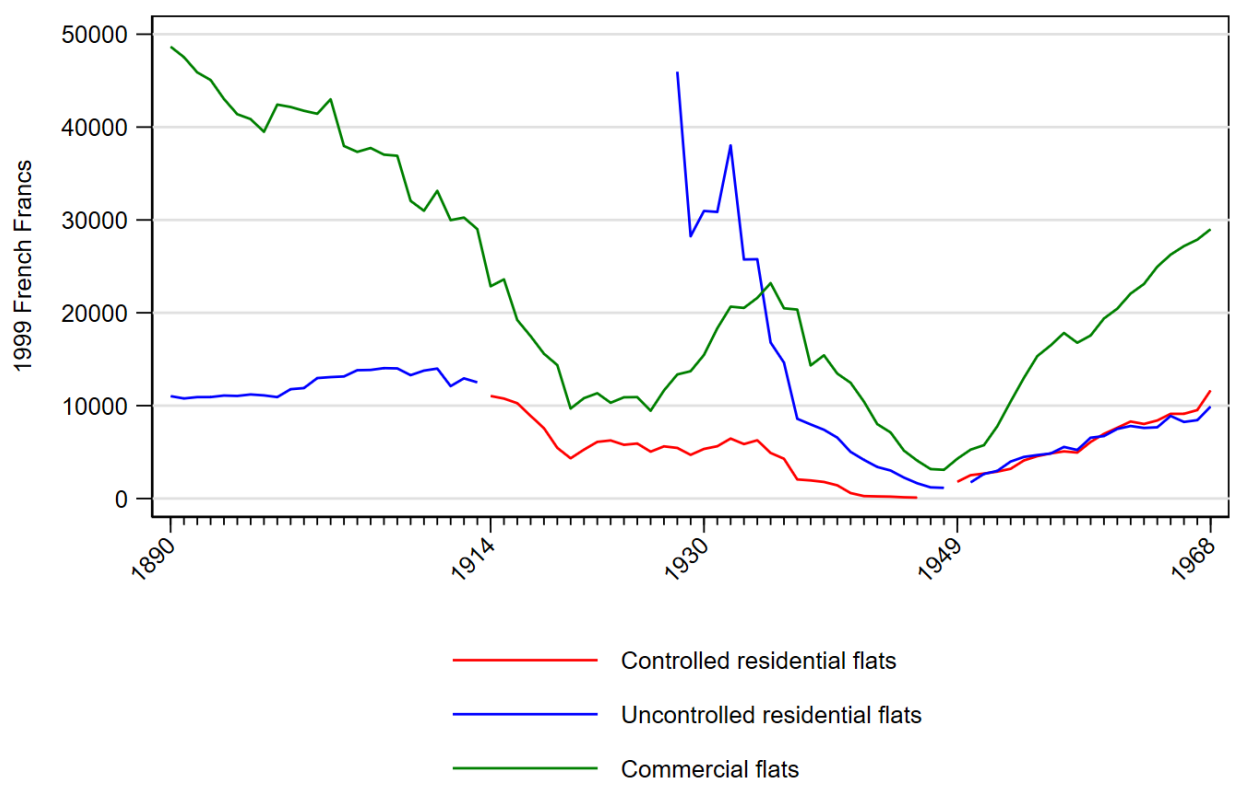

Figure 6: Logarithm of nominal rents of controlled residential flats, uncontrolled residential flats and commercial flats

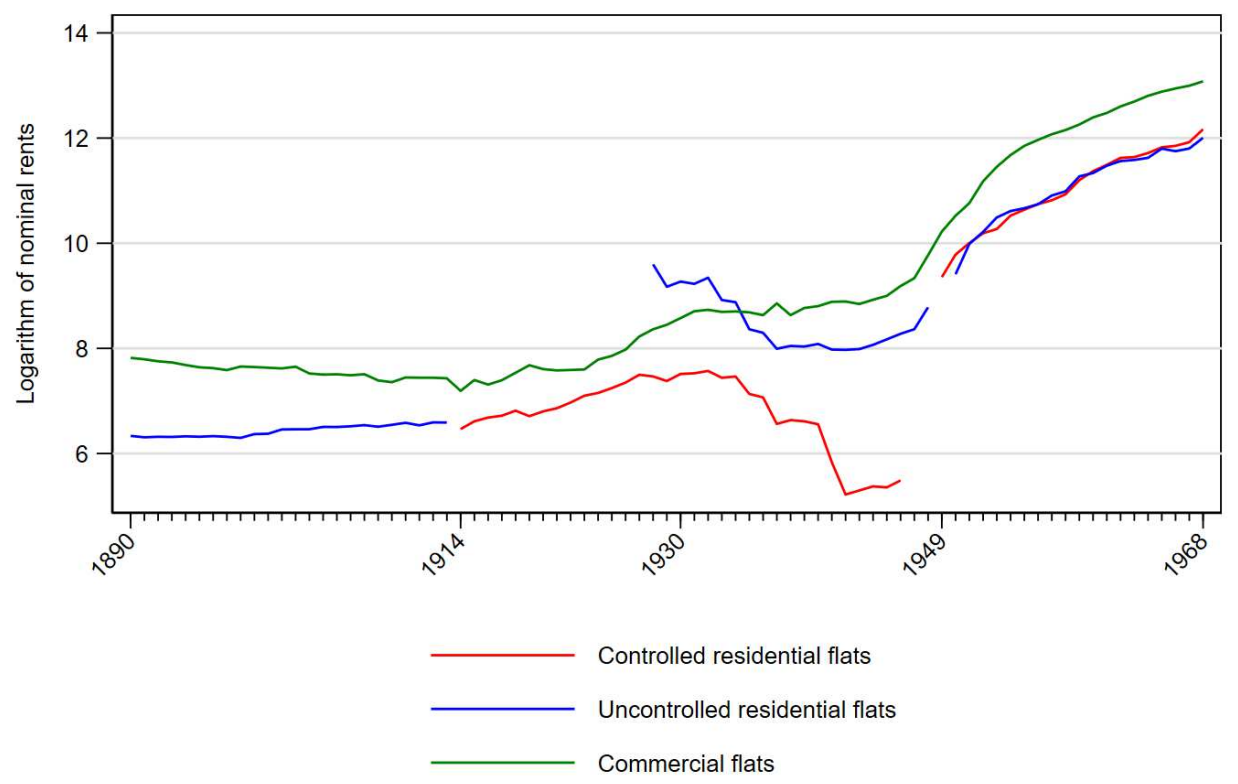


Figure 7: Test of the parallel trend assumption: Year coefficients and 95\% CIs for flats which were controlled at least once (flats never controlled as reference).
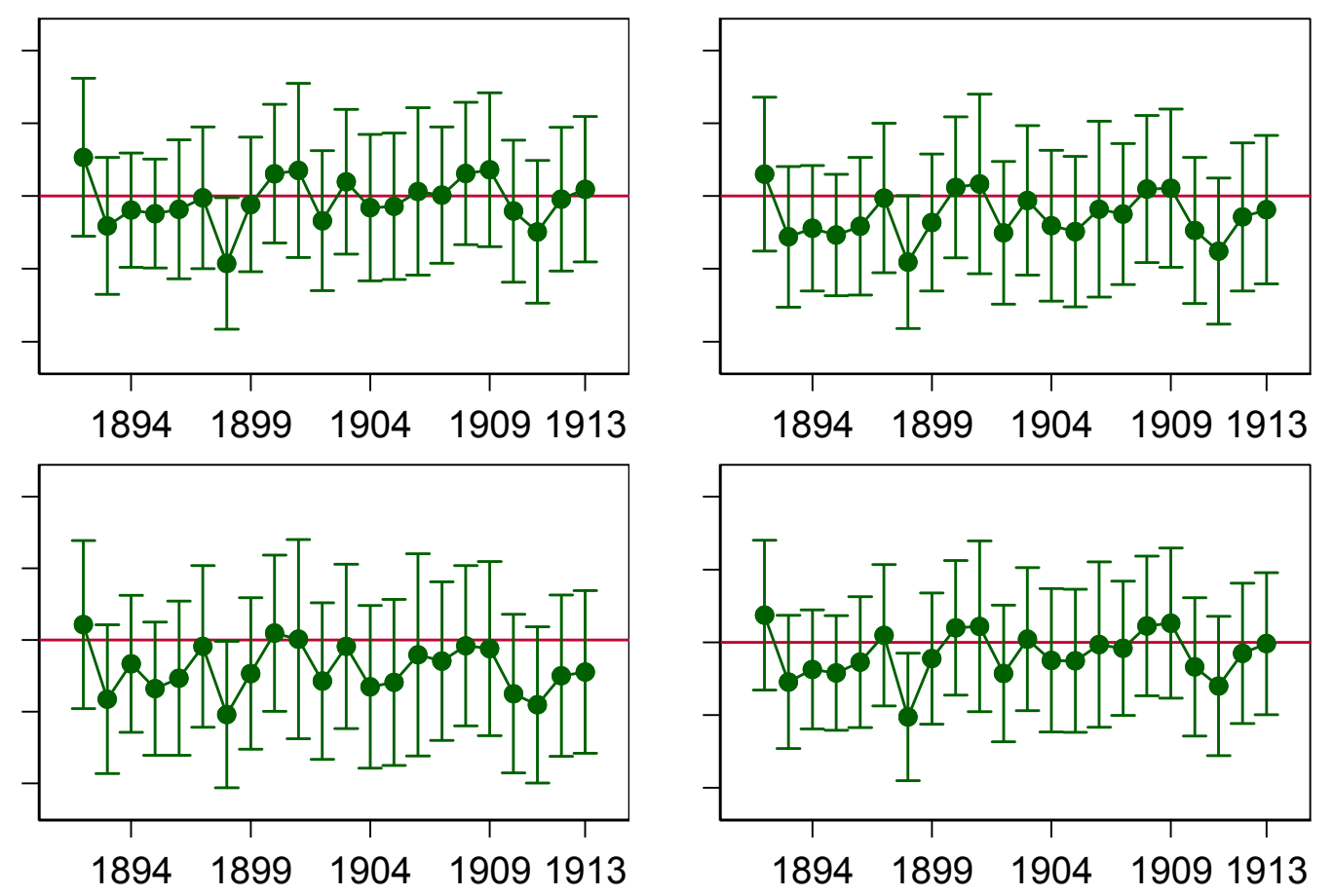

Note: From left to right and top to bottom: (a) sample of flats present at least once during the 1st and 2nd subperiods (232 flats, 74 shops); (b) sample of flats present at least once during the 1st and 3rd subperiods (200 flats, 74 shops); (c) sample of flats present at least once during the 1st and 4th subperiods (172 flats, 63 shops); (d) whole sample (292 flats, 101 shops). 1st subperiod: 1890-1913, 2nd subperiod: 1914-1929, 3rd subperiod: 19301948, 4th subperiod: 1949-1968. 
Figure 8: Annual tenants' mobility rates in residential flats

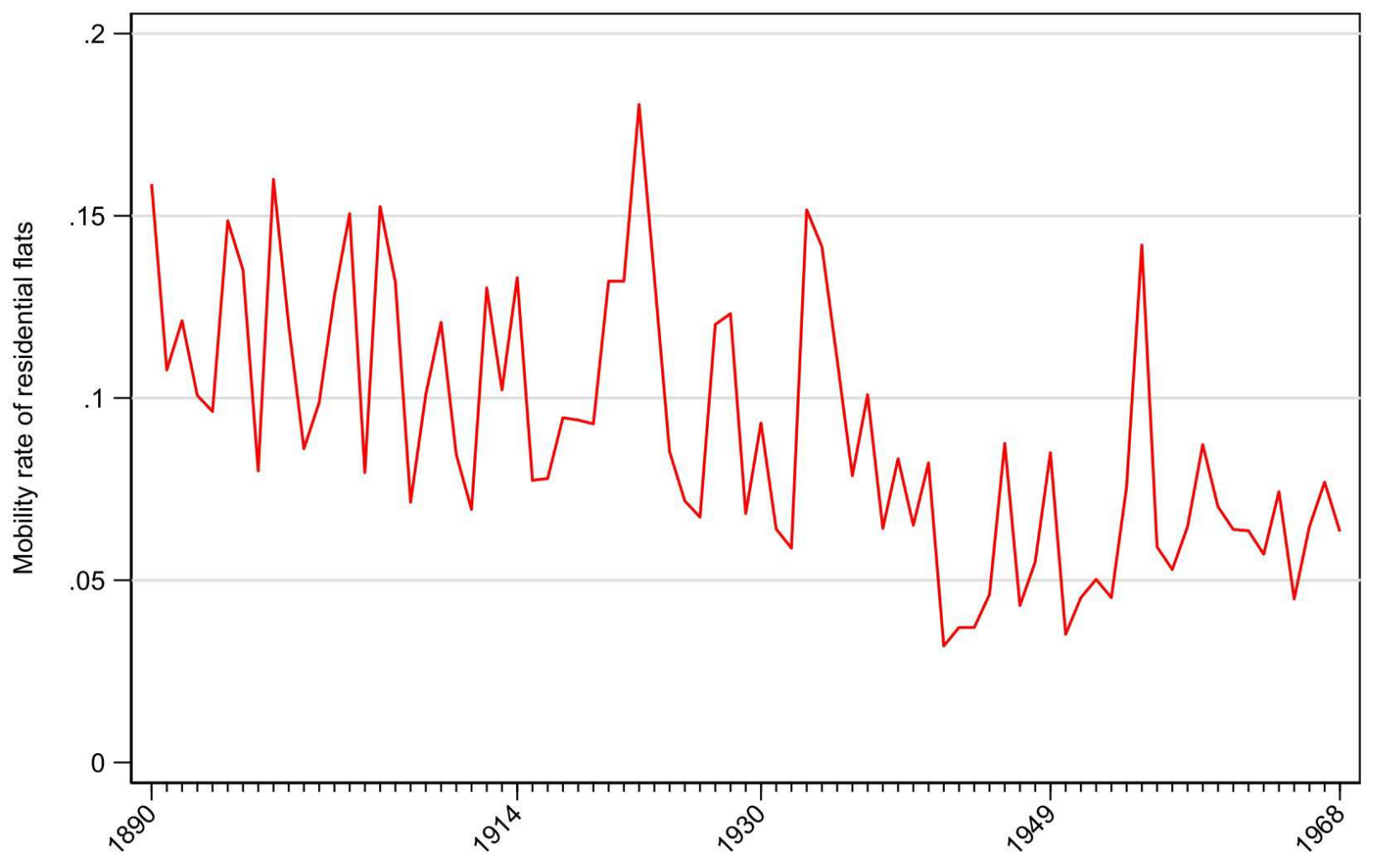


Table 1: Rent control policy description

\begin{tabular}{|c|c|c|}
\hline Period & Type of control & Detailed description \\
\hline 1890-1913 & None & \\
\hline 1914-1929 & Second-generation & $\begin{array}{l}\text { Rent moratorium for rents below 600Fr until } 1918 . \\
\text { Cap in rent increases for rents below a ceiling after } \\
1918 \text {, } \\
\text { e.g. nominal rents in } 1926 \text { cannot exceed twice their } \\
1914 \text { level. }\end{array}$ \\
\hline 1930-1948 & First generation & $\begin{array}{l}\text { Rents were capped except that they exceeded the ceil- } \\
\text { ing. For example, rents above } 350 \text { French Francs were } \\
\text { not controlled anymore since } 1942 \text {. }\end{array}$ \\
\hline 1949-1968 & Second-generation & $\begin{array}{l}\text { Definition of a reference rent based on housing charac- } \\
\text { teristics. } \\
\text { Regulated biannual rent increases so as to reach the } \\
\text { reference rent by } 1955 \text { for continuous leases. } \\
\text { Capped rent increase for continuous leases. }\end{array}$ \\
\hline
\end{tabular}

Table 2: Average numbers of flats by year for each sub-period

\begin{tabular}{ccccc}
\hline & \multicolumn{2}{c}{ Uncontrolled flats } & Controlled flats & \multirow{2}{*}{ Total } \\
\cline { 2 - 4 } & Commercial & Residential & Residential & \\
\hline $1890-1913$ & 46.2 & 168.4 & 0 & 214.6 \\
$1914-1929$ & 68.5 & 1.1 & 192.7 & 262.3 \\
$1930-1948$ & 74.2 & 138.7 & 74.3 & 287.2 \\
$1949-1968$ & 65.7 & 62.1 & 113.9 & 241.7 \\
\hline
\end{tabular}


Table 3: Sample summary statistics

\begin{tabular}{|c|c|c|c|c|c|c|c|c|c|c|c|}
\hline & \multicolumn{2}{|c|}{$1890-1913$} & \multicolumn{3}{|c|}{$1914-1929$} & \multicolumn{3}{|c|}{ 1930-1948 } & \multicolumn{3}{|c|}{$1949-1968$} \\
\hline & Uncontrolled & Commercial & Controlled & Uncontrolled & Commercial & Controlled & Uncontrolled & Commercial & Controlled & Uncontrolled & Commercial \\
\hline Rent & $\begin{array}{l}12,636 \\
(13,023)\end{array}$ & $\begin{array}{l}31,298 \\
(22,566)\end{array}$ & $\begin{array}{l}6,610 \\
(8,426)\end{array}$ & $\begin{array}{l}35,785 \\
(17,637)\end{array}$ & $\begin{array}{l}9,829 \\
(8,773)\end{array}$ & $\begin{array}{l}5,060 \\
(3,256)\end{array}$ & $\begin{array}{l}5,590 \\
(8,166)\end{array}$ & $\begin{array}{l}9,107 \\
(10,870)\end{array}$ & $\begin{array}{l}4,045 \\
(3,340)\end{array}$ & $\begin{array}{l}7,185 \\
(6,669)\end{array}$ & $\begin{array}{l}13,025 \\
(13,584)\end{array}$ \\
\hline Number of rooms & $\begin{array}{l}3.28 \\
(1.58)\end{array}$ & $\begin{array}{l}4.17 \\
(1.57)\end{array}$ & $\begin{array}{l}3.45 \\
(1.75)\end{array}$ & $\begin{array}{l}6.64 \\
(3.11)\end{array}$ & $\begin{array}{l}3.24 \\
(1.37)\end{array}$ & $\begin{array}{l}2.87 \\
(1.15)\end{array}$ & $\begin{array}{l}3.64 \\
(1.70)\end{array}$ & $\begin{array}{l}3.21 \\
(1.61)\end{array}$ & $\begin{array}{l}3.21 \\
(1.31)\end{array}$ & $\begin{array}{l}3.40 \\
(1.91)\end{array}$ & $\begin{array}{l}3.33 \\
(1.55)\end{array}$ \\
\hline \multicolumn{12}{|l|}{ Floor } \\
\hline Surface per room & $\begin{array}{l}23.15 \\
(10.32)\end{array}$ & $\begin{array}{l}30.99 \\
(4.19)\end{array}$ & $\begin{array}{l}21.86 \\
(9.40)\end{array}$ & $\begin{array}{l}29.80 \\
(8.55)\end{array}$ & $\begin{array}{l}31.63 \\
(3.80)\end{array}$ & $\begin{array}{l}20.19 \\
(7.37)\end{array}$ & $\begin{array}{l}22.06 \\
(7.83)\end{array}$ & $\begin{array}{l}31.25 \\
(3.82)\end{array}$ & $\begin{array}{l}20.76 \\
(7.16)\end{array}$ & $\begin{array}{l}22.37 \\
(8.05)\end{array}$ & $\begin{array}{l}31.69 \\
(3.83)\end{array}$ \\
\hline 1st or ground floor & $\begin{array}{l}0.16 \\
(0.37)\end{array}$ & $\begin{array}{l}1.00 \\
(0.00)\end{array}$ & $\begin{array}{l}0.21 \\
(0.41)\end{array}$ & $\begin{array}{l}0.36 \\
(0.50)\end{array}$ & $\begin{array}{l}1.00 \\
(0.00)\end{array}$ & $\begin{array}{l}0.14 \\
(0.35)\end{array}$ & $\begin{array}{l}0.23 \\
(0.42)\end{array}$ & $\begin{array}{l}1.00 \\
(0.00)\end{array}$ & $\begin{array}{l}0.14 \\
(0.35)\end{array}$ & $\begin{array}{l}0.23 \\
(0.42)\end{array}$ & $\begin{array}{l}1.00 \\
(0.00)\end{array}$ \\
\hline 2nd-4th Floor & $\begin{array}{l}0.58 \\
(0.49)\end{array}$ & $\begin{array}{l}0.00 \\
(0.00)\end{array}$ & $\begin{array}{l}0.59 \\
(0.49)\end{array}$ & $\begin{array}{l}0.64 \\
(0.50)\end{array}$ & $\begin{array}{l}0.00 \\
(0.00)\end{array}$ & $\begin{array}{l}0.54 \\
(0.50)\end{array}$ & $\begin{array}{l}0.58 \\
(0.49)\end{array}$ & $\begin{array}{l}0.00 \\
(0.00)\end{array}$ & $\begin{array}{l}0.61 \\
(0.49)\end{array}$ & $\begin{array}{l}0.47 \\
(0.50)\end{array}$ & $\begin{array}{l}0.00 \\
(0.00)\end{array}$ \\
\hline 5th-6th Floor & $\begin{array}{l}0.26 \\
(0.44)\end{array}$ & $\begin{array}{l}0.00 \\
(0.00)\end{array}$ & $\begin{array}{l}0.21 \\
(0.40)\end{array}$ & $\begin{array}{l}0.00 \\
(0.00)\end{array}$ & $\begin{array}{l}0.00 \\
(0.00)\end{array}$ & $\begin{array}{l}0.31 \\
(0.46)\end{array}$ & $\begin{array}{l}0.18 \\
(0.39)\end{array}$ & $\begin{array}{l}0.00 \\
(0.00)\end{array}$ & $\begin{array}{l}0.24 \\
(0.43)\end{array}$ & $\begin{array}{l}0.30 \\
(0.46)\end{array}$ & $\begin{array}{l}0.00 \\
(0.00)\end{array}$ \\
\hline \multicolumn{12}{|l|}{ Construction type and period } \\
\hline Ancient ${ }^{*}$ before 1871 & $\begin{array}{l}0.29 \\
(0.46)\end{array}$ & $\begin{array}{l}0.39 \\
(0.49)\end{array}$ & $\begin{array}{l}0.35 \\
(0.48)\end{array}$ & $\begin{array}{l}0.00 \\
(0.00)\end{array}$ & $\begin{array}{l}0.54 \\
(0.50)\end{array}$ & $\begin{array}{l}0.42 \\
(0.49)\end{array}$ & $\begin{array}{l}0.33 \\
(0.47)\end{array}$ & $\begin{array}{l}0.59 \\
(0.49)\end{array}$ & $\begin{array}{l}0.41 \\
(0.49)\end{array}$ & $\begin{array}{l}0.46 \\
(0.50)\end{array}$ & $\begin{array}{l}0.51 \\
(0.50)\end{array}$ \\
\hline Haussmannian*before 1871 & $\begin{array}{l}0.10 \\
(0.30)\end{array}$ & $\begin{array}{l}0.38 \\
(0.49)\end{array}$ & $\begin{array}{l}0.11 \\
(0.31)\end{array}$ & $\begin{array}{l}0.18 \\
(0.40)\end{array}$ & $\begin{array}{l}0.12 \\
(0.33)\end{array}$ & $\begin{array}{l}0.09 \\
(0.29)\end{array}$ & $\begin{array}{l}0.13 \\
(0.33)\end{array}$ & $\begin{array}{l}0.20 \\
(0.40)\end{array}$ & $\begin{array}{l}0.09 \\
(0.29)\end{array}$ & $\begin{array}{l}0.12 \\
(0.33)\end{array}$ & $\begin{array}{l}0.19 \\
(0.39)\end{array}$ \\
\hline Ancient*1871-1914 & $\begin{array}{l}0.21 \\
(0.40)\end{array}$ & $\begin{array}{l}0.00 \\
(0.00)\end{array}$ & $\begin{array}{l}0.15 \\
(0.36)\end{array}$ & $\begin{array}{l}0.09 \\
(0.30)\end{array}$ & $\begin{array}{l}0.00 \\
(0.00)\end{array}$ & $\begin{array}{l}0.12 \\
(0.33)\end{array}$ & $\begin{array}{l}0.15 \\
(0.36)\end{array}$ & $\begin{array}{l}0.00 \\
(0.00)\end{array}$ & $\begin{array}{l}0.14 \\
(0.34)\end{array}$ & $\begin{array}{l}0.03 \\
(0.18)\end{array}$ & $\begin{array}{l}0.00 \\
(0.00)\end{array}$ \\
\hline Haussmannian*1871-1914 & $\begin{array}{l}0.40 \\
(0.49)\end{array}$ & $\begin{array}{l}0.23 \\
(0.43)\end{array}$ & $\begin{array}{l}0.39 \\
(0.49)\end{array}$ & $\begin{array}{l}0.73 \\
(0.47)\end{array}$ & $\begin{array}{l}0.34 \\
(0.48)\end{array}$ & $\begin{array}{l}0.37 \\
(0.48)\end{array}$ & $\begin{array}{l}0.39 \\
(0.49)\end{array}$ & $\begin{array}{l}0.21 \\
(0.41)\end{array}$ & $\begin{array}{l}0.36 \\
(0.48)\end{array}$ & $\begin{array}{l}0.38 \\
(0.49)\end{array}$ & $\begin{array}{l}0.31 \\
(0.46)\end{array}$ \\
\hline District & & & & & & & & & & & \\
\hline 1st arrondissement & $\begin{array}{l}0.20 \\
(0.40)\end{array}$ & $\begin{array}{l}0.56 \\
(0.50)\end{array}$ & $\begin{array}{l}0.26 \\
(0.44)\end{array}$ & $\begin{array}{l}0.36 \\
(0.50)\end{array}$ & $\begin{array}{l}0.72 \\
(0.45)\end{array}$ & $\begin{array}{l}0.35 \\
(0.48)\end{array}$ & $\begin{array}{l}0.29 \\
(0.46)\end{array}$ & $\begin{array}{l}0.60 \\
(0.49)\end{array}$ & $\begin{array}{l}0.34 \\
(0.47)\end{array}$ & $\begin{array}{l}0.43 \\
(0.49)\end{array}$ & $\begin{array}{l}0.64 \\
(0.48)\end{array}$ \\
\hline 2nd arrondissement & $\begin{array}{l}0.40 \\
(0.49)\end{array}$ & $\begin{array}{l}0.44 \\
(0.50)\end{array}$ & $\begin{array}{l}0.36 \\
(0.48)\end{array}$ & $\begin{array}{l}0.18 \\
(0.40)\end{array}$ & $\begin{array}{l}0.28 \\
(0.45)\end{array}$ & $\begin{array}{l}0.35 \\
(0.48)\end{array}$ & $\begin{array}{l}0.32 \\
(0.47)\end{array}$ & $\begin{array}{l}0.40 \\
(0.49)\end{array}$ & $\begin{array}{l}0.27 \\
(0.45)\end{array}$ & $\begin{array}{l}0.27 \\
(0.45)\end{array}$ & $\begin{array}{l}0.36 \\
(0.48)\end{array}$ \\
\hline 3rd arrondissement & $\begin{array}{l}0.18 \\
(0.39)\end{array}$ & $\begin{array}{l}0.00 \\
(0.00)\end{array}$ & $\begin{array}{l}0.14 \\
(0.34)\end{array}$ & $\begin{array}{l}0.18 \\
(0.40)\end{array}$ & $\begin{array}{l}0.00 \\
(0.00)\end{array}$ & $\begin{array}{l}0.11 \\
(0.32)\end{array}$ & $\begin{array}{l}0.15 \\
(0.35)\end{array}$ & $\begin{array}{l}0.00 \\
(0.00)\end{array}$ & $\begin{array}{l}0.21 \\
(0.41)\end{array}$ & $\begin{array}{l}0.09 \\
(0.28)\end{array}$ & $\begin{array}{l}0.00 \\
(0.00)\end{array}$ \\
\hline 5th arrondissement & $\begin{array}{l}0.08 \\
(0.27)\end{array}$ & $\begin{array}{l}0.00 \\
(0.00)\end{array}$ & $\begin{array}{l}0.08 \\
(0.26)\end{array}$ & $\begin{array}{l}0.00 \\
(0.00)\end{array}$ & $\begin{array}{l}0.00 \\
(0.00)\end{array}$ & $\begin{array}{l}0.08 \\
(0.27)\end{array}$ & $\begin{array}{l}0.08 \\
(0.28)\end{array}$ & $\begin{array}{l}0.00 \\
(0.00)\end{array}$ & $\begin{array}{l}0.10 \\
(0.30)\end{array}$ & $\begin{array}{l}0.11 \\
(0.31)\end{array}$ & $\begin{array}{l}0.00 \\
(0.00)\end{array}$ \\
\hline 6th arrondissement & $\begin{array}{l}0.14 \\
(0.35)\end{array}$ & $\begin{array}{l}0.00 \\
(0.00)\end{array}$ & $\begin{array}{l}0.16 \\
(0.37)\end{array}$ & $\begin{array}{l}0.27 \\
(0.47)\end{array}$ & $\begin{array}{l}0.00 \\
(0.00)\end{array}$ & $\begin{array}{l}0.11 \\
(0.31)\end{array}$ & $\begin{array}{l}0.16 \\
(0.37)\end{array}$ & $\begin{array}{l}0.00 \\
(0.00) \\
\end{array}$ & $\begin{array}{l}0.07 \\
(0.26)\end{array}$ & $\begin{array}{l}0.10 \\
(0.30)\end{array}$ & $\begin{array}{l}0.00 \\
(0.00)\end{array}$ \\
\hline Observations & 4042 & 1108 & 2942 & 13 & 1053 & 1260 & 2293 & 1221 & 1879 & 1016 & 1059 \\
\hline
\end{tabular}

Note: Currency amounts are expressed in 1999 Fr. Standard deviations between parentheses. Within subperiods, the composition of each subsample evolves over years as some residential flats are released from control. 
Table 4: Rent control impact on rents: estimations for different periods and samples

\begin{tabular}{lcccc}
\hline $\begin{array}{l}\text { Time period } \\
\text { Sample }\end{array}$ & $\begin{array}{c}1890-1929 \\
\text { Quasi-balanced } \\
(1)\end{array}$ & $\begin{array}{c}1890-1948 \\
\text { Quasi-balanced } \\
(2)\end{array}$ & $\begin{array}{c}1890-1968 \\
\text { Quasi-balanced } \\
(3)\end{array}$ & $\begin{array}{c}1890-1968 \\
\text { No restriction } \\
(4)\end{array}$ \\
\hline 2nd gen. rent control, & -0.242 & -0.259 & -0.364 & -0.368 \\
1914-1929 & $(0.078)^{* * *}$ & $(0.083)^{* * *}$ & $(0.152)^{* * *}$ & $(0.080)^{* * *}$ \\
& {$[0.101]^{* *}$} & {$[0.105]^{* *}$} & {$[0.166]^{* *}$} & {$[0.093]^{* * *}$} \\
1st gen. rent control, & & & & \\
1930-1948 & & -0.0911 & -0.145 & -0.165 \\
& $(0.025)^{* * *}$ & $(0.030)^{* * *}$ & $(0.028)^{* * *}$ \\
2nd gen. rent control, & & {$[0.037]^{* *}$} & {$[0.038]^{* * *}$} & {$[0.041]^{* * *}$} \\
1949-1968 & & & & \\
& & & -0.042 & -0.051 \\
\hline Flat fixed effects & & & $(0.036)$ & $(0.034)$ \\
Year dummies $\times$ flat use & Yes & Yes & {$[0.031]$} & {$[0.031]$} \\
Observations & 9034 & 12859 & Yes & Yes \\
Distinct flats & 306 & 274 & 15320 & Yes \\
$\mathrm{R}^{2}$ & 0.627 & 0.796 & 235 & 19639 \\
\hline
\end{tabular}

Note: $* \mathrm{p}<0.1, * * \mathrm{p}<0.05, * * * \mathrm{p}<0.01$. Standard errors in parentheses are clustered at the flat level. Standard errors in square brackets are clustered at the building level. Dependent variable is log of rent. All regressions include flat fixed effects. Column (1) restricts the sample to flats which are present both before 1914 and after 1914. Column (2) restricts the sample to flats which are present both before 1914 and after 1929. Column (3) restricts the sample to flats which are present both before 1914 and after 1948. Column (4) uses the whole sample without any restriction. 
Table 5: Rent control impact on rents: robustness checks with different control groups

\begin{tabular}{lccc}
\hline Control group & $\begin{array}{c}\text { Baseline } \\
(1)\end{array}$ & $\begin{array}{c}\text { Without flats released } \\
\text { From rent control } \\
(2)\end{array}$ & $\begin{array}{c}\text { Commercial flats only } \\
(3)\end{array}$ \\
\hline 2nd gen. rent control, & -0.364 & -0.123 & -0.11 \\
1914-1929 & $(0.152)^{* *}$ & $(0.037)^{* * *}$ & $(0.037)^{* * *}$ \\
& {$[0.166]^{* * *}$} & {$[0.035]^{* * *}$} & {$[0.035]^{* * *}$} \\
1st gen. rent control, & -0.145 & -0.344 & -0.326 \\
1930-1948 & $(0.030)^{* * *}$ & $(0.051)^{* * * *}$ & $(0.052)^{* * *}$ \\
2nd gen. rent control, & {$[0.038]^{* * *}$} & {$[0.070]^{* * *}$} & {$[0.070]^{* * *}$} \\
1949-1968 & -0.042 & -0.488 & -0.465 \\
& $(0.036)$ & $(0.056)^{* * *}$ & $(0.057)^{* * * *}$ \\
\hline Flat fixed effects & {$[0.031]$} & {$[0.062]^{* * *}$} & {$[0.064]^{* * *}$} \\
Year dummies $\times$ flat use & Yes & Yes & Yes \\
Year dummies & Yes & & \\
Observations & & Yes & Yes \\
Distinct flats & 15320 & 12285 & 12158 \\
$\mathrm{R}^{2}$ & 235 & 235 & 235 \\
\hline
\end{tabular}

Note: $* \mathrm{p}<0.1, * * \mathrm{p}<0.05, * * * \mathrm{p}<0.01$. Standard errors in parentheses are clustered at the flat level. Standard errors in square brackets are clustered at the building level. Dependent variable is log of rent. Samples are restricted to flats which are present both before 1914 and after 1948. Column (1) is replicated from Column (3) in Table 4. In Column (2), flats which have been released from rent control are dropped from the control group. In Column (3), only commercial flats are included in the control group. Due to the restrictions applied to the control group, interactions between flat use and year dummies are replaced by year dummies in Columns (2) and (3) so as to avoid multicollinearity issues. 
${ }^{1}$ More precisely, it was implemented in the municipality of Paris starting on August 1, 2015, suspended in November 2017 due to legal recourses from landlords' associations, and reintroduced on July 1, 2019.

${ }^{2}$ See Malard and Poulhès (2020) for a report on the impacts of the recent rent control policy in Paris and details about this law.

${ }^{3}$ See Gross (2020) for a recent example of benefits of rent control to renters.

${ }^{4}$ When comparing our data with a census conducted in Lyon in 1895 , we observe that high rents in 1895, above $400 \mathrm{Fr}$, are over-represented in our data. However, we find lower differences if we compare rents in our data with those in the family budget surveys carried out by the Prefecture of the Rhône in the subsequent periods.

${ }^{5}$ Note that there are a few dwellings which happened to be never treated. However, the vast majority of them disappear after 1914, and will not be selected in our estimation sample for reasons specified in the following.

${ }^{6}$ Our estimation sample is not strictly speaking a balanced panel, because we only require the flats to be observed at least one year before rent control starts, and at least one year during the rent control period; however, this selection rule gives a sample which is practically similar to a balanced panel, with only few units leaving the sample before the end of the period considered. 